\title{
Aliskiren: Direct Renin Inhibitor Baru pada Terapi Hipertensi
}

\author{
Dewi, N. P. U. S. ${ }^{*}$, I. G. A. A. E. Amandari ${ }^{1}$, M. W. Krisnayanti ${ }^{1}$, M. A. Sarasmita ${ }^{1}$ \\ 1Program Studi Farmasi Fakultas Matematika dan Ilmu Pengetahuan Alam Universitas Udayana, \\ Jalan Kampus Unud, Jimbaran, 80364 \\ *Corresponding author e-mail: umasaridewi@yahoo.com
}

Riwayat artikel: Dikirim: 26-05-2019; Diterima: 07-06-2019, Diterbitkan: 21-01-2020

\begin{abstract}
ABSTRAK
Hipertensi merupakan kondisi ketika tekanan darah meningkat secara kronis. Mengacu pada hasil Riset Kesehatan Dasar (Riskesdas), Bali memiliki proporsi hipertensi sebesar 19,9\%. Beberapa studi epidemiologis menyebutkan bahwa risiko kerusakan berbagai organ vital secara langsung berkorelasi dengan peningkatan tekanan darah. Oleh karena itu, diperlukan keteraturan dalam mengontrol dan juga meminum obat antihipertensi. Obat antihipertensi yang umum digunakan saat ini adalah angiotensin converting enzyme inhibitor (ACEI) dan angiotensin receptor blocker (ARB). Akan tetapi, temuan sebelumnya menyatakan bahwa ACEI dan ARB belum sepenuhnya efektif dalam menurunkan tekanan darah. Untuk mengatasi kelemahan tersebut, ditemukan direct renin inhibitor baru yaitu aliskiren. Aliskiren dapat memblokade renin-angiotensin-aldosterone system (RAAS) pada level tertinggi, sehingga kemampuan aliskiren dalam menurunkan tekanan darah tidak dapat diragukan lagi. Aliskiren mampu menghambat konversi angiotensinogen menjadi angiotensin I, sehingga dapat menurunkan tekanan darah secara berkelanjutan.
\end{abstract}

Kata kunci: Aliskiren, direct renin inhibitor, hipertensi

ABSTRACT
Hypertension is a condition when blood pressure increases chronically. Referring to the results of Riset Kesehatan Dasar (Riskesdas), Bali has a proportion of hypertension of $19.9 \%$. Several epidemiological studies suggest that the risk of damage to various vital organs directly correlates with an increase in blood pressure. Therefore, it takes regularity in controlling and also taking antihypertensive drugs. The most common antihypertensive drugs currently used are angiotensin converting enzyme inhibitors (ACEI) and angiotensin receptor blockers (ARBs). However, previous findings suggest that ACEI and ARB have not been fully effective in lowering blood pressure. To overcome these weaknesses, found a new direct renin inhibitor that is aliskiren. Aliskiren can block the renin-angiotensin-aldosterone system (RAAS) at the highest level, so the ability of aliskiren in lowering blood pressure can not be doubted. Aliskiren able to inhibit the conversion of angiotensinogen to angiotensin I, so it can lower blood pressure in a sustainable manner.

Keywords: Aliskiren, direct renin inhibitor, hypertension

\section{PENDAHULUAN}

Hipertensi merupakan kondisi ketika tekanan darah meningkat secara kronis. Pada tahun 2000, tercatat sebanyak 26,4\% dari seluruh orang di dunia menderita hipertensi. Jumlah penderita hipertensi di seluruh dunia telah meningkat secara substansial antara tahun 2000 hingga 2010, angka kejadian hipertensi pada tahun 2010 dilaporkan meningkat menjadi 31,1\%. Sebanyak 31,5\% dari keseluruhan penderita hipertensi berasal dari negara dengan pendapatan rendah-menengah, salah satunya Indonesia (Riskesdas, 2013). Prevalensi hipertensi di Indonesia mencapai angka 25,8\% (Kemenkes RI, 2014). Mengacu pada hasil Riset Kesehatan Dasar
(Riskesdas) (2013), Bali memiliki proporsi hipertensi sebesar 19,9\%.

Beberapa studi epidemiologis menyebutkan bahwa risiko kerusakan berbagai organ vital, seperti ginjal, jantung, dan otak secara langsung berkorelasi dengan peningkatan tekanan darah. Oleh karena itu, diperlukan keteraturan dalam mengontrol dan juga meminum obat antihipertensi. Pemberian obat antihipertensi bertujuan untuk mencegah morbiditas dan mortalitas akibat tingginya tekanan darah dan mengendalian faktor-faktor risiko kardiovaskuler lainnya (Kemenkes RI, 2014).

Obat antihipertensi yang umum digunakan saat ini adalah angiotensin converting ensyme inbibitor 
(ACEI) dan angiotensin receptor blocker (ARB). Keduanya turut terlibat dalam mengendalikan renin-angiotensin-aldosterone system (RAAS). Akan tetapi, temuan sebelumnya menyatakan bahwa ACEI dan ARB belum sepenuhnya efektif karena keduanya dapat menghasilkan efek supresi RAAS yang inkomplit, sehingga dapat membatasi potensi kedua obat tersebut. Aliskiren merupakan direct renin inhibitor yang dapat memblokade RAAS pada level tertinggi, di mana akan menghambat konversi angiotensinogen menjadi angiotensin I (Brown, 2008).

Review ini akan mengulas karakteristik aliskiren sebagai antihipertensi dan penggunaannya secara klinis.

\section{SIFAT FISIKOKIMIA ALISKIREN}

Aliskiren merupakan molekul yang cenderung hidrofilik dengan nilai $\log \mathrm{P}$ oktanol/air sebesar 2,45 pada $\mathrm{pH} 7,4$. Selain itu, aliskiren memiliki kelarutan tinggi dalam air $(>350$ $\mathrm{mg} / \mathrm{mL}$ pada $\mathrm{pH} 7,4$ ) yang dianggap sebagai prasyarat penting untuk meningkatkan bioavalabilitas oral. Aliskiren memiliki bentuk basa bebas ( $\mathrm{pKa}$ sebesar 9,49) dengan rumus molekul $\mathrm{C}_{30} \mathrm{H}_{53} \mathrm{~N}_{3} \mathrm{O}_{6}$ dan berat molekul sebesar $551,8 \mathrm{gram} / \mathrm{mol}(609,8 \mathrm{gram} / \mathrm{mol}$ sebagai garam hemi-fumarat) (Brown, 2008). Berikut merupakan struktur molekul aliskiren.

\section{MEKANISME KERJA ALISKIREN}

Peranan RAAS dalam homeostasis sistem kardiovaskuler, tekanan darah, serta keseimbangan cairan dan elektrolit sudah diketahui sejak lama. RAAS dimulai dari adanya angiotensinogen. Angiotensinogen diproduksi di hati. Oleh renin, angiotensinogen akan mengalami konversi menjadi angiotensin I. Selanjutnya, angiotensin converting ensyme (ACE) akan mengonversi angiotensin I menjadi angiotensin II. Produksi angiotensin II secara terus-menerus dapat menyebabkan vasokonstriksi, peningkatan aldosteron, dan retensi cairan yang akhirnya akan menimbulkan hipertensi (Burchum and Rosenthal, 2016).

Aliskiren merupakan direct renin inbibitor dengan potensi tinggi yang bekerja pada renin untuk menghambat konversi angiotensinogen menjadi angiotensin I. Berdasarkan uji klinis, aliskiren mampu menurunkan aktivitas renin plasma sebesar 50\% hingga 80\% (Brown, 2008). Gambar 2 menunjukkan tempat aksi dari beberapa golongan antihipertensi.

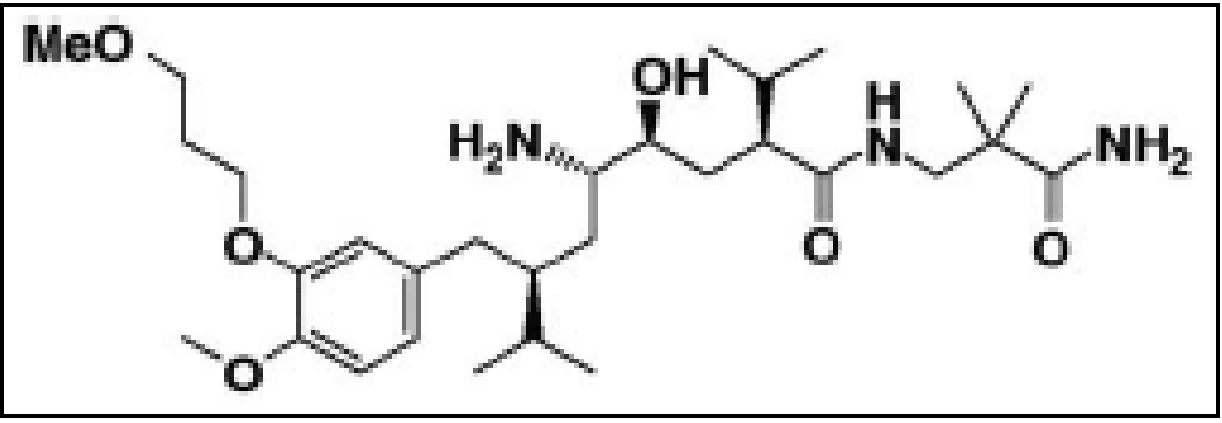

Gambar 1. Rumus Struktur Aliskiren (Brown, 2008) 


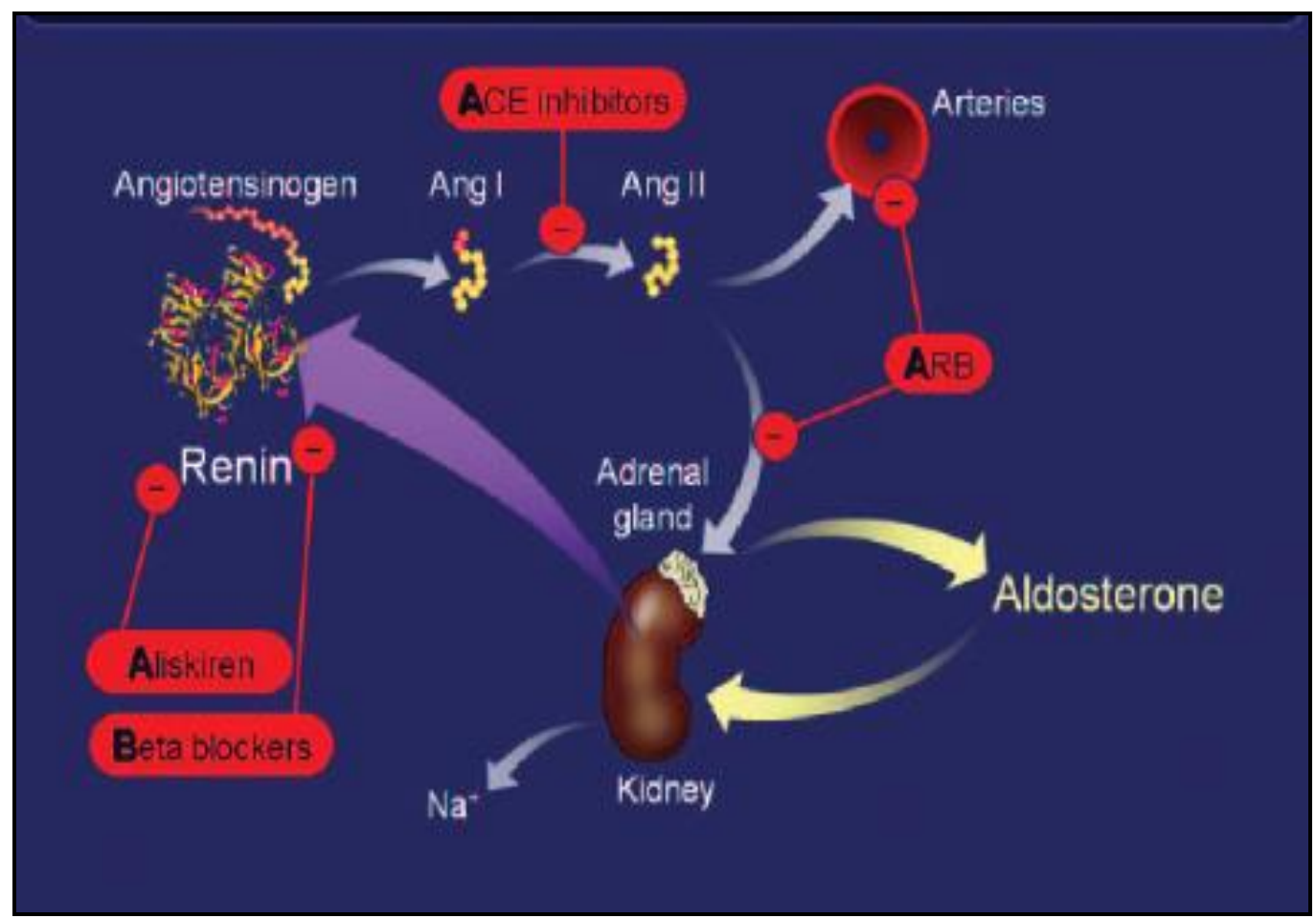

Gambar 2. Tempat Aksi dari Beberapa Golongan Antihipertensi (Brown, 2008)

\section{FARMAKOKINETIK- \\ FARMAKODINAMIK ALISKIREN}

Aliskiren memiliki waktu paruh hingga 40 jam, sehingga membuatnya mampu mengendalikan tekanan darah selama 24 jam dan keuntungannya dapat diberikan one-daily dosing, dengan bioavailabilitas oral sebesar 2,5\%. Setelah 1-3 jam pemberian, maka akan diperoleh konsentrasi puncak aliskiren dalam plasma, namun onset ini dapat tertunda atau menurun secara substansial dengan adanya makanan tinggi lemak (Schmieder et al.; 2007; Cromer and Peker, 2008). Setelah pemberian bersamaan dengan makanan tinggi lemak, maka konsentrasi AUC dan konsentrasi puncak plasma menurun masingmasing sebesar 71\% dan 85\% (Brown, 2008). Kondisi tunak dicapai setelah waktu 5-8 hari pada pemberian one-daily dosing. Profil farmakokinetik aliskiren tidak terpengaruh oleh ras, usia, jenis kelamin, gangguan hepar (Child-Pugh Clinical Assessment Score 5-15), gangguan ginjal (klirens kreatinin $<80 \mathrm{~mL} /$ menit), dan diabetes (Wal et al., 2011).

Sebanyak 50\% aliskiren terikat dengan protein plasma di dalam sirkulasi, dengan nilai volume distribusi pada kepustakaan sebesar 135 L. Jalur metabolisme utama aliskiren melalui ekskresi bilier sebagai unmetabolized drug dan kurang dari 1\% aliskiren yang diberikan secara oral diekskresi melalui ginjal. Aliskiren pun dimetabolisme oleh sitokrom P450 (predominan oleh isoenzim sitokrom P3A4) (Sica, 2009).

Beberapa penelitian pre-klinis dan klinis membuktikan bahwa aliskiren mampu menurunkan aktivitas plasma renin dan konsentrasi angiotensin, baik angiotensin I maupun angiotensin II. Oleh karena itu, potensi aliskiren tidak dapat diragukan karena aliskiren mampu memblokade RAAS secara efektif (Izzo et al., 2008).

\section{PENGGUNAAN KLINIS ALISKIREN Dosis Aliskiren}

Aliskiren tersedia dalam bentuk sediaan tunggal (Tekturna ${ }^{\circledR}$ dan Rasilez ${ }^{\circledR}$ ) maupun kombinasi. Contoh sediaan kombinasi yang beredar di pasaran adalah aliskirenhidroklorotiazid (HCT) (Tekturna HCT dan Rasilez HCT) dan aliskiren-amlodipin (Tekamlo). Tekturna ${ }^{\circledR}$ dan Rasilez ${ }^{\circledR}$ tersedia dalam bentuk tablet dengan dosis $150 \mathrm{mg}$ dan $300 \mathrm{mg}$. Dosis awal terapi aliskiren yaitu $150 \mathrm{mg} /$ hari. Jika tekanan darah belum terkontrol, maka dosis dapat ditingkatkan hingga $300 \mathrm{mg} /$ hari. Namun, apabila dosis harian aliskiren diberikan di atas $300 \mathrm{mg}$, maka risiko diare akan meningkat. Beberapa 


\section{Dewi, dkk.}

DOI : https://doi.org/10.24843/JFU.2019.v08.i02.p01

pISSN: 2301-7716; eISSN: 2622-4607

Jurnal Farmasi Udayana, Vol 8, No 2, Tahun 2019, 59-65

penelitian menyebutkan bahwa makanan tinggi lemak mampu menurunkan absorpsi aliskiren secara substansial, sehingga setiap dosis harian aliskiren harus diberikan 1 jam sebelum makan (Burchum and Rosenthal, 2016).

Menurut Strasser et al. (2007), monoterapi aliskiren menunjukkan hasil yang efektif dalam menurunkan tekanan darah. Parallel-group study yang dilakukan Strasser et al. (2007) pada pasien dengan hipertensi berat untuk membandingkan tolerabilitas dan efikasi antara aliskiren 150 $\mathrm{mg} /$ hari dengan lisinopril $20 \mathrm{mg} /$ hari, menunjukkan bahwa aliskiren $150 \mathrm{mg}$ memiliki efek yang mirip dengan lisinopril $20 \mathrm{mg}$ dalam menurunkan tekanan darah sistolik (SBP) dan diastolik (DBP).

Pada Januari 2008, Food and Drug Administration (FDA) telah menyetujui kombinasi aliskiren-HCT dengan empat variasi strength (kekuatan)/dosis obat yaitu $150 \mathrm{mg} / 12,5 \mathrm{mg} ; 150$ $\mathrm{mg} / 25 \mathrm{mg} ; 300 \mathrm{mg} / 12,5 \mathrm{mg}$; dan $300 \mathrm{mg} / 25 \mathrm{mg}$ untuk pemakaian sekali sehari, di mana terapi kombinasi digunakan jika ditemukan respon yang tidak adekuat pada masing-masing monoterapi (Burchum and Rosenthal, 2016). Placebo-controlled study oleh Villamil et al. (2007) menunjukkan bahwa monoterapi aliskiren $75 \mathrm{mg} ; 150 \mathrm{mg}$; atau $300 \mathrm{mg}$; HCT 6,25 mg; 12,5 mg; atau $25 \mathrm{mg}$, dan terapi kombinasi aliskiren-HCT $75 \mathrm{mg} / 6,25 \mathrm{mg}$; $75 \mathrm{mg} / 12,5 \mathrm{mg} ; 75 \mathrm{mg} / 25 \mathrm{mg} ; 150 \mathrm{mg} / 6,25 \mathrm{mg}$; $150 \mathrm{mg} / 12,5 \mathrm{mg} ; 150 \mathrm{mg} / 25 \mathrm{mg} ; 300 \mathrm{mg} / 12,5$ $\mathrm{mg}$; dan $300 \mathrm{mg} / 25 \mathrm{mg}$, seluruhnya mampu menurunkan SBP secara signifikan dibandingkan dengan plasebo. Namun, hanya beberapa kombinasi aliskiren-HCT $(75 \mathrm{mg} / 6,25 \mathrm{mg} ; 75$ $\mathrm{mg} / 25 \mathrm{mg} ; 150 \mathrm{mg} / 12,5 \mathrm{mg} ; 150 \mathrm{mg} / 25 \mathrm{mg} ; 300$ $\mathrm{mg} / 12,5 \mathrm{mg}$; dan $300 \mathrm{mg} / 25 \mathrm{mg}$ ) yang terbukti mampu menurunkan SBP dan DBP dibandingkan dengan monoterapi masing-masing komponen. Berdasarkan penelitian Villamil et al. (2007), diketahui pula bahwa terapi kombinasi aliskirenHCT mampu mengurangi kejadian hipokalemia dibandingkan dengan pasien yang menerima monoterapi HCT.

Terapi kombinasi aliskiren-amlodipin (Tekamlo) pun tersedia dalam empat variasi strength (kekuatan)/dosis obat yaitu $150 \mathrm{mg} / 5 \mathrm{mg}$; $150 \mathrm{mg} / 10 \mathrm{mg} ; 300 \mathrm{mg} / 5 \mathrm{mg}$; dan $300 \mathrm{mg} / 10 \mathrm{mg}$ untuk pemakaian sekali sehari. Studi Drummond et al. (2007) menunjukkan bahwa pasien yang menerima terapi kombinasi aliskiren-amlodipin $150 \mathrm{mg} / 5 \mathrm{mg}$ nyatanya mengalami penurunan SBP dan DBP yang signifikan dibandingkan dengan pasien yang menerima monoterapi amlodipin $5 \mathrm{mg}$.

\section{Adverse Effect dan Keamanan Aliskiren}

Aliskiren termasuk obat yang dapat ditoleransi dengan baik dalam dosis oral tunggal maupun kombinasi. Adverse effect yang umum terjadi pada pasien adalah angioedema baik pada wajah, ekstremitas, bibir, lidah, glotis atau laring, diare, sakit kepala, nasofaringitis, kelelahan, infeksi saluran pernafasan atas, dan nyeri punggunng (Burchum and Rosenthal, 2016).

Aliskiren termasuk dalam kategori $C$ pada kehamilan trimester pertama dan kategori $\mathrm{D}$ pada kehamilan trimester kedua dan ketiga. $\mathrm{Hal}$ tersebut belum dievaluasi pada wanita hamil, tetapi beberapa literatur menyebutkan bahwa pemakaian aliskiren harus segera dihentikan setelah kehamilan terdeteksi. Obat-obatan yang bekerja pada RAAS dapat menyebabkan mortalitas dan morbiditas janin dan bayi. Beberapa literatur melaporkan bahwa morbiditas janin dan bayi akibat pemakaian obat-obatan yang bekerja pada RAAS selama masa kehamilan berupa hipotensi, neonatal skull bypoplasia, anuria, gagal ginjal reversibel atau ireversibel, oligohidramnion, dan kematian. Risiko dan manfaat harus dipertimbangkan dengan hati-hati untuk wanita hamil, jika tidak ada pengobatan alternatif yang tersedia, janin harus dipantau secara ketat. Selain itu, aliskiren diekskresikan dalam ASI tikus, tetapi belum dievaluasi pada manusia. Oleh karena itu, wanita yang berencana untuk menyusui harus menghentikan penggunaan aliskiren (Cromer and Peker, 2008).

\section{Interaksi Obat Aliskiren}

Aliskiren tidak mempengaruhi aktivitas enzim sitokrom P450, dimetabolisme minimal oleh CYP3A4, dan tidak terikat dengan protein, sehingga aliskiren memiliki potensi rendah untuk berinteraksi dengan obat lain (Brown, 2008).

Dieterle et al. (2004) telah membuktikan bahwa beberapa dosis aliskiren tidak memiliki efek terhadap farmakodinamik atau farmakokinetik dari dosis tunggal warfarin. Selain itu, aliskiren tidak menunjukkan adanya interaksi 
farmakokinetik yang relevan secara klinis dengan lovastatin, atenolol, celecoxib, atau simetidin pada responden pria yang sehat. Dieterich et al. (2006) pun menyebutkan bahwa aliskiren tidak memiliki interaksi dengan digoxin.

Namun, uji klinis lain menunjukkan bahwa terdapat interaksi antara aliskiren dengan beberapa obat tertentu. Menurut Vaidyanathan et al. (2006), pemberian aliskiren bersamaan dengan furosemide mampu menurunkan konsentrasi AUC dan konsentrasi puncak plasma furosemide masing-masing hingga 30\% dan 50\%. Selain itu, pemberian ketoconazole pada dosis $200 \mathrm{mg}$ setiap dua kali sehari berhubungan dengan peningkatan kadar plasma aliskiren hingga 80\% (Brown, 2008).

\section{Perbedaan Aliskiren dengan Obat Hipertensi Lain yang Bekerja pada RAAS}

Obat antihipertensi yang umum digunakan saat ini adalah ACEI dan ARB. Selain kedua obat tersebut, telah ditemukan obat baru yang turut bekerja pada RAAS yaitu aliskiren. Ketiganya mempunyai site action yang berbeda, namun memiliki tujuan yang sama yaitu menghambat RAAS (Brown, 2008). Berikut merupakan jalur renin-angiotensin-aldosterone system (RAAS) serta beberapa obat hipertensi yang bekerja pada RAAS.
Aliskiren bekerja dengan cara menghambat sekresi renin, menyebabkan penurunan produksi angiotensin I maupun angiotensin II, sedangkan ACEI menghambat angiotensin converting ensyme (ACE) yang akan mengonversi angiotensin I menjadi angiotensin II, sehingga menurunkan kadar angiotensin II. ARB sendiri mampu berinteraksi pada reseptor AT-1, sehingga angiotensin II tidak dapat bereaksi dengan reseptor. Ketiganya bertujuan untuk mencegah vasokonstriksi, peningkatan aldosteron, dan retensi cairan yang akhirnya akan mencegah terjadinya hipertensi (Brown, 2008).

Walaupun ACEI dan ARB bekerja pada jalur RAAS, namun keduanya belum sepenuhnya efektif dalam menghambat RAAS dibandingkan dengan aliskiren. ACEI merupakan inhibitor pembentukan angiotensin II, hal tersebut akan menyebabkan peningkatan aktivitas renin oleh karena rusaknya siklus umpan balik yang normalnya akan menghambat pengeluaran renin dari ginjal. ACEI pun menghambat inaktivasi bradikinin dan substansi $P$, sehingga memunculkan efek samping batuk dan angioedema (Brown, 2008; Nadeem and Batisky, 2014).

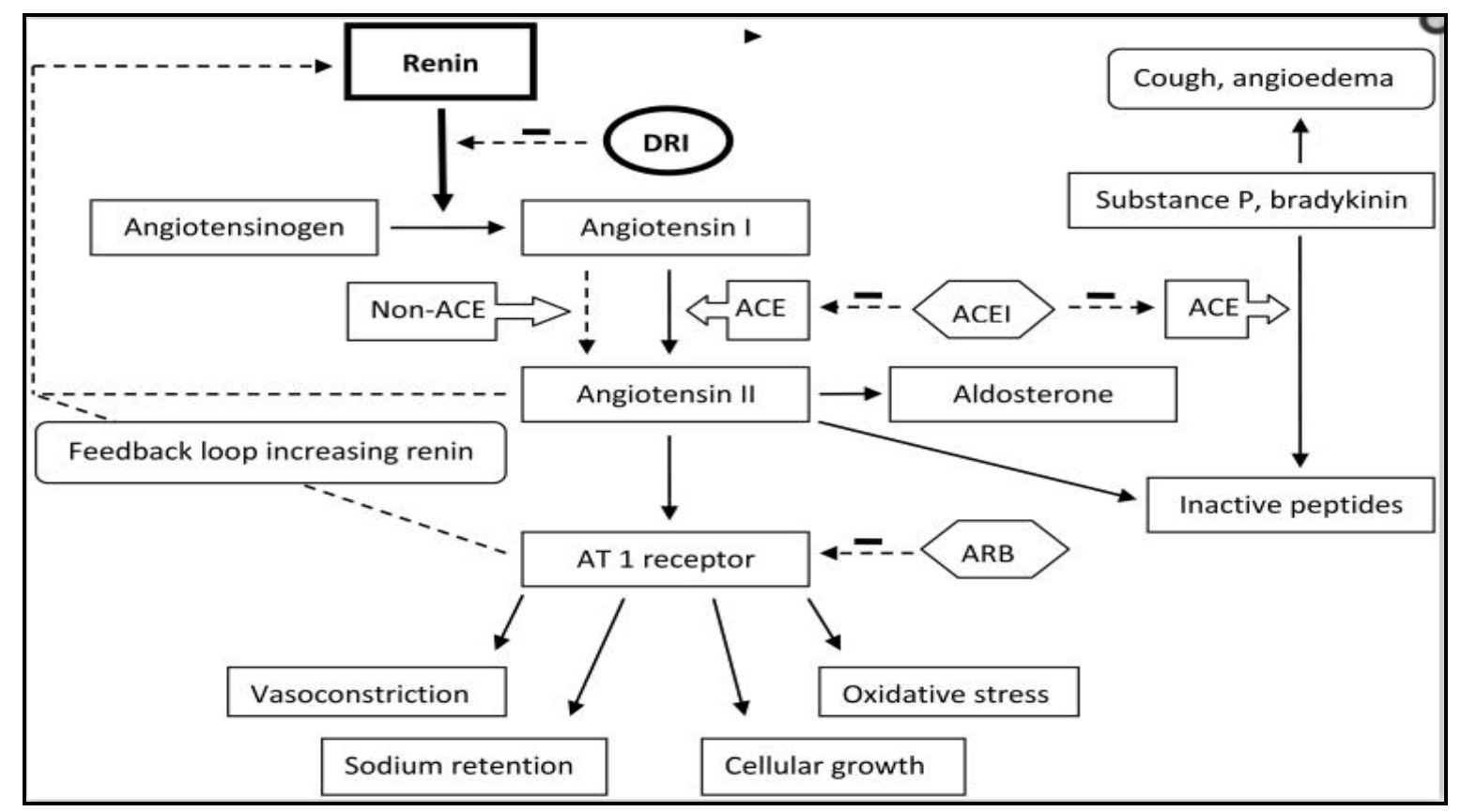

Gambar 3. Jalur Renin-Angiotensin-Aldosterone System (RAAS) serta Beberapa Obat Hipertensi yang Bekerja pada RAAS (Nadeem and Batisky, 2014) 


\section{Dewi, dkk.}

DOI : https://doi.org/10.24843/JFU.2019.v08.i02.p01

pISSN: 2301-7716; eISSN: 2622-4607

Jurnal Farmasi Udayana, Vol 8, No 2, Tahun 2019, 59-65

Sejauh ini hanya inhibitor renin yang dapat menghambat jalur RAAS secara selektif dan efektif dengan memblok renin pada siklus RAAS. ARB mampu memblok reseptor AT-1 secara spesifik, sehingga angiotensin II tidak berinteraksi pada reseptor tersebut. Namun, selain reseptor AT-1 terdapat reseptor lain seperti reseptor AT-2 yang dapat diaktivasi oleh angiotensin II karena akumulasi konsentrasi angiotensin II. Jalur pengaktifan reseptor AT-2 ini pun menghasilkan efek yang berbahaya, seperti proliferasi sel vaskuler, terbentuknya fragmen angiotensin (ang 1-7, ang III, dan ang IV) dalam konsentrasi tinggi (Burchum and Rosenthal, 2016).

Beberapa studi menunjukkan bahwa ang IV dapat merangsang prothrombotic plasminogen activator inbibitor-1 dan mengakibatkan efek protrombotik, vasokonstriktor, dan efek tropik yang tidak diinginkan. ACEI dan ARB dapat meningkatkan akitivitas renin plasma melalui hambatan umpan balik negatif. Hal tersebut dapat mengakibatkan kerusakan organ target seperti disfungsi renal dan hipertrofi ventrikel kiri. Dengan adanya inhibitor renin yang dapat menekan aktivitas renin, baik dengan monoterapi maupun kombinasi dengan ACEI atau ARB, diharapkan dapat mencegah kerusakan organ target pada hipertensi (Nadeem and Batisky, 2014).

\section{KESIMPULAN}

Hipertensi merupakan kondisi ketika tekanan darah meningkat secara kronis, sehingga diperlukan keteraturan dalam mengontrol dan juga meminum obat antihipertensi. Obat antihipertensi yang umum digunakan saat ini adalah angiotensin converting ensyme inbibitor (ACEI) dan angiotensin receptor blocker (ARB). Akan tetapi, ACEI dan ARB belum sepenuhnya efektif dalam menurunkan tekanan darah. Untuk itu, ditemukan direct renin inbibitor baru yaitu aliskiren. Aliskiren dapat memblokade renin-angiotensin-aldosterone system (RAAS) pada level tertinggi, sehingga aliskiren dapat menurunkan tekanan darah secara berkelanjutan.

\section{UCAPAN TERIMAKASIH}

Ucapan terima kasih disampaikan kepada seluruh pihak yang senantiasa memberikan dukungan moral kepada penulis.

\section{DAFTAR PUSTAKA}

Brown, M. J. 2008. Aliskiren. Circulation. 118: 773784.

Burchum, J. and L. Rosenthal. 2016. Lehne's Pharmacotherapeutics for Nurse Practitioners and Physician Assistants. St. Louis: Elsevier.

Cromer, J. and S. Peker. 2008. Aliskiren (Tekturna), A Novel Antihypertensive Approach to Inhibition of the ReninAngiotensin-Aldosterone System. Drug Forecast. 33(2): 92-96.

Dieterich, H., et al. 2006. Aliskiren, the First in a New Class of Orally Effective Renin Inhibitors, Has No Clinically Significant Drug Interactions with Digoxin in Healthy Volunteers. Clin. Pharmacol. Ther. 79: 64.

Dieterle, W. et al. 2004. Effect of the Oral Renin Inhibitor Aliskiren on the Pharmacokinetics and Pharmacodynamics of a Single Dose of Warfarin in Healthy Subjects. Br. J. Clin. Pharmacol. 58: 433-436.

Drummond, W., et al. Antihypertensive Efficacy of the Oral Direct Renin Inhibitor Aliskiren as Add-on Therapy in Patients Not Responding to Amlodipine Monotherapy. J. Clin. Hypertens. 9: 742-750.

Izzo, J. L. et al. 2008. Hypertension Primer. $4^{\text {th }}$ Edition. USA: Lippincott Williams and Wilkins.

Kemenkes RI. 2014. Infodatin: Hipertensi. Jakarta: Kementerian Kesehatan Republik Indonesia.

Nadeem, S. and D. L. Batisky. 2014. Aliskiren, the First Direct Renin Inhibitor: Assessing a Role in Pediatric Hypertension and Kidney Diseases. Pediatric Nephrology. 29(11): 21052111.

Riskesdas. 2013. Riset Kesehatan Dasar. Jakarta: Kementerian Kesehatan Republik Indonesia.

Schmieder, R. E., et al. 2007. Aliskiren-based Therapy Lowers Blood Pressure More Effectively than Hydrochlorothiazide-based Therapy in Patients with Hypertension. J. Clin. Hypertens. 9: 182.

Sica, D. A. 2009. Textbook of Nephro-Endocrinology. St. Louis: Elsevier.

Strasser, R. H., et al. 2007. A Comparison of the Tolerability of the Direct Renin Inhibitor Aliskiren and Lisinopril in Patients with 
DOI : https://doi.org/10.24843/JFU.2019.v08.i02.p01

pISSN: 2301-7716; eISSN: 2622-4607

Jurnal Farmasi Udayana, Vol 8, No 2, Tahun 2019, 59-65

Severe Hypertension. J. Hum. Hypertens. 21: Villamil, A., et al. 2007. Renin Inhibition with 780-787.

Vaidyanathan, S., et al. Aliskiren, a Novel Orally Effective Renin Inhibitor, Exhibits Similar Pharmacokinetics and Pharmacodynamics in Japanese and Caucasian Subjects. Br. J. Clin. Pharmacol. 62(6): 690-698. Aliskiren Provides Additive Antihypertensive Efficacy when Used in Combination with Hydrochlorothiazide. J. Hypertens. 25(1): 217-226.

Wal, P., et al. 2011. Aliskiren: An Orally Active Renin Inhibitor. Journal of Pharmacy and Bioallied Sciences. 3(2): 189-193. 